\title{
Communication Strategies, ELF and ELT materials
}

\author{
Estratégias de comunicação, Inglês como Lingua Franca (ILF) e Materiais Ensino de \\ Lingua Inglesa (ELI)
}

\author{
Paola Vettorel \\ Università di Verona \\ Verona, Itália
}

\begin{abstract}
This paper discusses how Communication Strategies are dealt with in a set of ELT course-books addressed at Italian secondary school students, published by local and international publishers between 1990 and 2015. After presenting CSs as a field of research, their relevance in English as a Lingua Franca communication is illustrated with reference to existing research in the field. The research design and findings from the study are then presented, and examples from the data are provided. It is shown how, apart from a few cases, CSs are not dealt with consistently in the ELT course-books under examination, and the current lingua franca role English increasingly plays not represented. Recommendations for future research and implications for pedagogic practices are also set forward.

Keywords: English as a Lingua Franca, Communication Strategies, ELT course-books
\end{abstract}

\begin{abstract}
Resumo: O texto busca discutir como Estratégias de Comunicação são trabalhadas em um grupo de coleções didáticas de língua inglesa usadas por estudantes secundaristas italianos, publicadas por editoras locais e internacionais entre os anos de 1990 e 2015. Após apresentar as ECs como um campo de pesquisa, ilustra-se sua relevância para a comunicação em Inglês como Língua Franca, fazendo-se referência às pesquisas já existentes na área. A organização e os achados do estudo são apresentados na sequência, assim como exemplos retirados dos dados levantados. Mostra-se, com algumas exceções, como as ECs não são usadas de forma consistente nos livros didáticos de língua inglesa examinados e como o papel do inglês como língua franca permanece quase que totalmente ignorado. Finalmente, são dadas algumas recomendações para pesquisas futuras e discutidas implicações para práticas pedagógicas.
\end{abstract}

Palavras-chave: Inglês como língua franca; Estratégias de Comunicação; Livros didáticos de Língua Inglesa.

\section{INTRODUCTION: STRATEGIC COMPETENCE, COMMUNICATION STRATEGIES AND ELF}

Communication Strategies (CSs henceforth) have been largely investigated since the 1980s, particularly within a Second Language Acquisition (SLA) perspective. CSs can be seen as the 'realization' of Strategic Competence, one of the components of Communicative Competence (e.g. CANALE; SWAIN, 1980). Going beyond compensatory and psychological approaches, Elaine Tarone proposed in the early 1980s an interactional approach, whereby CSs were seen as "mutual attempts of two interlocutors to agree on a meaning in situations where the requisite meaning structures do not seem to be shared" (TARONE, 1980, p. 420, cf. also TARONE, 1981).

In the following years, and particularly since the late 1990s, many researchers have focused on the importance of adopting an interactional approach in looking at how meaning is socially co-constructed in interactions, and at the fundamental role that CSs play in meaning negotiation. CSs started to be explored as tools to support both speaker

* Professora da Universidade de Verona, Itália. Email: paola.vettorel@univr.it. 
and listener in cooperatively co-constructed and negotiated meaning, to be employed to 'enhance the effectiveness of communication' (CANALE, 1983). In Wagner and Firth's words, "one central feature in conversation is that participants constantly and conjointly stretch their meaning-creating potential, often, it seems, to the limit [...] Speakers attempt to use all available information in a conversation as a resource to create and continually (re)negotiate interpersonal meaning" (1997, p. 342). Within an interactional perspective, a variety of pragmatic moves such as requests for repetition, clarification, paraphrases, reformulation and the like are thus seen as naturally employed, both in L1 and in L2 interactions, to the aim of reaching effective communication in a cooperative manner.

The spread of English in the world, with its diversification (World Englishes) and the extended Lingua Franca (ELF) function this language increasingly plays in a plethora of domains, from business to academia and digital settings, means that opportunities to communicate through ELF have not only exponentially multiplied, but also become part of our everyday life. It has been shown by ELF research that CSs are widely deployed by ELF speakers to co-construct meaning, and strategic competence constitutes part and parcel of ELF users' communicative repertoire, together with, or as part of, their 'lingual capability' (WIDDOWSON 2003; SEIDLHOFER, 2011) to exploit the 'virtual language' as well as their plurilingual resources to the aim of effective and meaningful communication. Since ELF users are at least bilingual, ELF interactions are "sites of multilingual contact by definition" (SEIDLHOFER, 2015, p. 8). This entails that English in these contexts is to be intended as a 'multilingua franca' (JENKINS, 2015), where codeswitching, polylingual languaging and/or translanguaging practices are used to express meaning, to accommodate and create rapport as well as to include (projected) personal and social identities (e.g. RAMPTON, 1997; FIRTH; WAGNER, 1997 [2007]; COGO, $2009,2012,2016)$. These multilingual practices have been shown to constitute an integral part of ELF; in Cogo's words, "code-switching is an expression of the bilingual or multilingual competence of the participants (and not of their deficiency) being able to draw on their multifaceted linguistic repertoire" (2009, p. 263), and "the participants' use of languages other than English is so intrinsic to ELF as to be seen as a constituted and constitutive part of it" (2009, p. 264). It should be pointed out that earlier research focused on code-switching looking at "how multilingual resources/distinct languages are separately integrated into the fabric of ELF discourse" (COGO 2018, p. 358, italics in the original). More recent approaches see the exploitation of the speakers' plurilingual repertoires in a more flexible and permeable way, such as "polylingual languaging" (JØRGENSEN 2008) and "translanguaging” (GARCİA; WEI, 2014) whereby language users draw on whatever (inter)lingual resources at their disposal in the realization of communicative acts in a flexible and dynamic way. Together with other CSs, these multilingual practices can be seen as part of ELF users' strategic competence, as an additional tool multilingual speakers can draw upon, and as an asset rather than a 'learner deficiency' measured against a monolingual, native-speaker idealised model benchmark.

Communication strategies have been a richly investigated area in ELF, above all in academia (MAURANEN, 2006, 2012; BJÖRKMAN, 2011, 2014; KAUR, 2009; 
BJØRGE, 2010; KONAKAHARA, 2012) and business (BELF) contexts (PITZL, 2010; COGO, 2009, 2012, 2016; FRANCESCHI, 2017); other studies have also examined more informal communication contexts, such as Erasmus/international students communities (e.g. KALOCSAI. 2013; JAFARI, 2016, 2017; JOKIĆ 2016; BATZIAKAS 2016), or the leisure domain in the VOICE Corpus ${ }^{1}$ (VETTOREL, 2017). These studies show that successful communication and mutual understanding are achieved, or pre-empted, through a broad range of CSs that are skilfully employed by the participants as "a joint enterprise of expressing meaning" (COGO; DEWEY, 2012, p. 103).

The underlying theoretical framework and rationale that has informed ELF research into CSs is one that sees them not as deficit moves carried out by non-native (permanent) learners to compensate for a lack in (linguistic) proficiency. CSs are rather conceived of as part of the communicative and 'lingual' capability of ELF users (SEIDLHOFER, 2015; WIDDOWSON, 2003, 2015). In this view, ELF speakers are oriented towards a collaborative co-construction of meaning making skilful use of pragmatic moves, and are capable of drawing on all the resources in their repertoires to jointly co-build and accomplish successful communication. CSs such as repetition, paraphrasing, rephrasing or clarification have been shown to be widely used in ELF interactions both on the side of the speaker and of the listener to enhance clarity and explicitness and as "“a way of overcoming linguistic and cultural barriers in the situation" to make their message as clear as possible to their interlocutors (MAURANEN, 2007, p. 257). In this perspective, CSs serve pragmatic and accommodative functions in ELF context, that are inherently characterized by the complex meeting of different lingua-cultures: speakers enact listeneroriented adaptive behaviours to avoid/pre-empt, or to resolve, possible nonunderstandings and hence enhance successful communication (e.g. COGO, 2009; COGO; DEWEY, 2012; MAURANEN, 2007, 2012; SEIDLHOFER, 2011). As Cogo sums up, "[t]hough predisposed to misunderstandings because of the variety of linguacultures involved, ELF communication displays surprisingly few problematic moments, and the participants show skilful use of various strategies to prevent non-understanding and ensure the smooth running of talk" (2009, p. 255-256).

\section{COMMUNICATION STRATEGIES AND ELT}

Most research into CSs has also dealt with pedagogic aspects and language teaching, above all, in relation to English. Two main views emerge from literature: some scholars believe that CSs cannot be formally and overtly taught, mainly on the ground that strategic transfer from the L1 is possible, or that they can only be acquired in real-life contexts (e.g. BIALYSTOK, 1990; KELLERMAN, 1991; CANALE; SWAIN, 1980); other scholars,

1 The Vienna-Oxford International Corpus of English (http:/ / voice.univie.ac.at) is one of the main corpora of English as a Lingua Franca, with about 1 million words of naturally-occurring, face-to-face spoken ELF communication. 
instead, argue in favour of the inclusion of CSs in formal instruction and class activities (e.g. DÖRNYEI, 1995; DÖRNYEI; THURREL 1991, 1994; CELCE-MURCIA; DÖRNYEI; THURRELL, 1995; TARONE, 1984; TARONE; YULE, 1989; SAVIGNON, 1972, 1997). Supporters of a 'teachability' perspective for CSs generally argue that 'teaching CSs' can be enacted both in terms of awareness-raising (not least for their usefulness), and by providing learners with CSs models and examples, as well as with ways and opportunities to cooperatively interact in L2 contexts (for an overview cf. DÖRNYEI, 1995; FAUCETTE, 2001).

Given the extended role as a lingua franca of communication that English retains today, and the relevance that CSs play in ELF interactions, raising awareness of their importance in English language teacher education and in ELT classroom practices has been called for by several ELF researchers. Seidlhofer, for example, has argued that the ways in which English is used as a lingua franca raises important conceptual issues and challenges in and for ELT. In her words, "[a]bandoning unrealistic notions of achieving 'perfect' communication through 'native-like' proficiency in English would free up resources for focusing on skills and procedures that are likely to be useful in EIL talk", that is, including CSs for instance in "signalling non-comprehension in a face-saving way, asking for repetition, paraphrasing, etc."; in this perspective, accommodation skills "such as drawing on extralinguistic cues, gauging interlocutors' linguistic repertoires, supportive listening" could be given more attention, too, within a multilingual and language awareness perspective (2004, p. 220, cf. also SEIDLHOFER, 2011).

In a similar vein, Watterson maintains that CSs should be included in language teaching materials and classroom practices in order to equip learners with tools to cope with diversity: 'in the 'open seas' (YOSHIDA, 2004, p. 15-16) of language use outside of language classrooms, these skills may be more crucial to communicative success than many of the linguistic details traditionally focused on within these same classrooms" (2008, p. 402). The same point is made by Cogo and Pitzl (2016): reporting several examples of CSs in ELF data, from partial repetition and paraphrase to minimal queries, the authors comment that ways to pre-empt and signal non-understandings are not adequately taken into account in ELT materials, despite their relevance in real-world interactions. For instance, examples of explicit minimal queries (e.g. 'again?'), that are "efficient in clearing up the understanding" and in the "joint construction of successful negotiation" could be included in teaching materials rather than, or together with, more elaborate linguistic forms that are in some cases presented (2016, p. 343).

Tarone, recalling that within Communicative Competence models ${ }^{2}$ Strategic Competence is "focused on use of alternative linguistic and non-linguistic structures to effectively achieve communication goals" (2016, p. 217), remarks that the tendency in ELT has been to focus above all on grammatical competence,

${ }^{2}$ Referring to Canale's (1983) model. 
damaging to second-language learners' development of overall communicative competence, but most particularly to their development of strategic competence, which is the essential ability to creatively and flexibly draw upon a range of different language forms and expressions in order to reach a communicative goal (ibid.).

Tarone also adds that, rather than uniformity, as often presented in class and materials,

there is inherent variability in proficient language performance when speakers are focused on reaching a communicative goal. This variability is the essence of strategic competence, which is the flexible and creative use of linguistic and nonlinguistic structures in order to effectively reach one's communicative goal. Strategic competence is the ability to engage in a divergent and open-ended communicative process, where there are many possible solutions (p. 218).

In pedagogic terms, she insightfully remarks, "[t]oo much focus on accuracy leads learners to produce simple, but accurate sentences. Trying to produce more complex sentences almost always temporarily reduces accuracy, and too many classroom students unfortunately believe that accuracy is all that matters" (Tarone 2016, p. 224). Moving towards this orientation would entail setting attention more on what learners can do and achieve in terms of communicative capability rather than on what they cannot do within a deficit perspective.

Including in ELT practices awareness of CSs, of their relevance in communication, as well as opportunities for practicing them, could then contribute to foster the development of a 'strategic capability' (WIDDOWSON, 1983, 2003) to deal with the variability, and with the 'unexpectednesses' of communication, that is such a relevant aspect particularly (though not only) for ELF. As Kohn points out, 'strategic communicative interaction' is one of the components of (communicative) ELF Competence $^{3}$, and in pedagogic terms

[s]uitable tasks should be designed around authentic ELF communication with a focus on meaning and community-related communication intentions, the identification and analysis of problems, and the exploration of strategic solutions. Relevant back-up support is provided by reflective follow-up and complementary learning about activities (2016, p. 28).

\section{COMMUNICATION STRATEGIES IN ELT MATERIALS}

\footnotetext{
${ }^{3}$ The other dimensions being awareness of ELF, ELF-aware comprehension and production, non-native speaker creativity (Kohn 2016).
} 
For the reasons outlined in the previous sections, including in ELT materials activities aiming at raising awareness of CSs, of their relevance in communication, as well as opportunities for active practice, could contribute to equip learners with tools for the development of strategic competence in order to enable them to effectively make use of CSs in communication. Since course-books continue to constitute a widely used and relevant tool in ELT practices, both for teachers and for learners (e.g. RICHARDS, 2002 cited in SIQUEIRA, 2015, p. 245), investigating whether, and how, CSs are present in ELT materials seems a first preliminary step.

Over the last decade a number of studies have examined ELT textbooks from a WE/ELF perspective, looking at whether the current plurality of English is represented in these materials from a linguistic and/or cultural point of view (e.g. VETTOREL; LOPRIORE, 2013; SIQUEIRA, 2015; YU, 2015, also for an overview of literature). Research has also looked into pragmatics in ELT course-books (e.g. MEIHAMI; KHANLARZADEH, 2015; MCCONACHY; HATA, 2013; REN; HAN, 2016), but, to my knowledge, only very few studies have so far focused specifically on CSs in pedagogic materials, and these were not from a WE/ELF viewpoint. Faucette (2001), for example, examined the inclusion of CSs in 9 ELT course-books and 8 teachers' resource books, concluding that only a few CSs are dealt with (e.g. circumlocution and appeal for assistance), and that "textbooks appear to offer few effective practice activities to develop communication strategy competence" (2001: 27). In a more recent work, Kim (2010) has researched CSs in Korean seventh grade English textbooks; her findings show that, despite CSs being present in these materials (above all maintenance strategies, i.e. providing active response and shadowing, and to a much lesser extent rephrasing and asking for repetition), other relevant CSs were largely underrepresented (e.g. paraphrasing) or absent (approximation, restructuring). More research looking into how CSs are dealt with in ELT materials from a WE/ELF perspective would help shed light on this area above all in pedagogic terms.

\section{CSS IN ITALIAN ELT COURSE-BOOKS: RESEARCH DESIGN/QUESTIONS}

The present paper is part of a larger research project, whose aim is to investigate whether ELT course-books addressed at Italian secondary school students incorporate activities related to the development of CSs, and, if so, to what extent and in which ways. A total of twenty ELT course-books published by well-known Italian and international publishers from 1991 to 2015 have been examined (see Appendix 1). These textbooks were selected as deemed representative of the different periods taken into consideration (the 1990s, the 2000s and 2010-2015), either as widely adopted in the Italian context, or as attention to communication strategies was in some ways declared in the materials.

In formulating the research questions and the criteria for the analysis, the choice of a CSs reference model was not an easy task, given the complexity of different taxonomies that have been developed in literature (e.g. DÖRNYEI; SCOTT, 1997; ELLIS, 1985, 
COHEN; MACARO, 2007). Celce-Murcia, Dörnyei and Thurrell's model of "Suggested components of Strategic Competence" (1995, p. 28) was considered an appropriate starting point for two main reasons: first, the CSs perspective on which the model is based is a communicatively and cooperatively oriented one, where strategic competence is viewed as "an ever-present, potentially usable inventory of skills, that allows a strategically competent speaker to negotiate messages and resolve problems or to compensate for deficiencies in any of the other underlying competencies" (1995, p. 11); secondly, the fact that this framework is pedagogically-based, and the strategies taken into consideration were selected as "most relevant to communicative language use and CLT" (1995, p. 26), was deemed relevant for this study. The different components in the model (Interactional, Achievement/Compensatory, Stalling/Time-gaining and Self-monitoring strategies) have hence constituted the basis to define the criteria for analysis. Avoidance or reduction strategies were excluded since my aim was to look at CSs within a cooperative meaningconstruction perspective.

The aforementioned components were then compared with findings from ELF research on CSs, intersecting the first with strategies that have been shown to be widely, and effectively, employed by ELF users. In general, it can be said that most of the elements in Celce-Murcia, Dörnyei and Thurrell's model overlap with the ones that have been investigated in ELF with the aim to show the role they play in the effective coconstruction and negotiation of meaning in ELF interactions (KIRKPATRIK, 2007; OLLINGER, 2012; BJÖRKMAN, 2014; MAURANEN, 2006, 2007; KAUR, 2009; COGO; PITZL, 2016). The study was thus guided by the following research macroquestions:

a. Are Interactional, Achievement/Compensatory, Stalling/Time-gaining and Selfmonitoring strategies taken into account in the material under consideration?

b. What kind of activities and tasks are included, and for which strategies?

In order to analyse and categorize findings for the set of textbooks under examination, CSs were grouped into the following four macro-areas, and Celce-Murcia, Dörnyei and Thurrell's framework was slightly adapted and/or integrated with categories examined in ELF research (see e.g. BJÖRKMAN, 2014 for an overview):

1. appeal for help (direct/indirect);

2. (a) meaning negotiation: requests for repetition, clarification, direct questions/minimal queries); (b) meaning negotiation: confirmation checks, direct/indirect question, repetition in rising intonation, interpretative summary (e.g. you mean...?), content / summary;

3. Responses: repetition, rephrasing, expansion, reduction/simplification, confirmation, rejection, repair; lexical anticipation / suggestion / correction (Kirkpatrick 2007); use of fillers and time-gaining devices; 
4. achievement strategies: circumlocution/paraphrase, approximation/all-purpose words/word-replacement, restructuring, word-coinage, code-switching - or literal translation from L1 (mother tongue)/Ln (any language part of the interactants' repertoire), foreignizing, code-switching into $\mathrm{L} 1 / \mathrm{L} 3 / \mathrm{Ln}$ )

As to macro-area 4, it should be pointed out that instances involving the exploitation of plurilingual repertoires, such as code-switching and word coinage, have been considered within a 'multicompetence' framework, that is, all the 'lingual' resources in the speakers' repertoires $(\mathrm{L} 1, \mathrm{~L} 3, \mathrm{Ln})$ are seen as part of the communication strategies employed with the aim of achieving co-constructed and negotiated meaning. As mentioned earlier, within the communication (and not deficit) perspective that underlies ELF research, the role of accommodation that code-switching and translanguaging practices play in ELF interactions, and the several functions they have been shown to retain for multilingual ELF users (KLIMPFINGER, 2007, 2009; COGO, 2009, 2010, 2012,2018 ) are to be considered as integral part of accommodative tools in interaction.

Course-books materials were thus analysed according to the criteria of the macroareas above, in all their components (Student's Book - SB, Workbook - WB, Teacher's Book/Guide - TB/TG), and findings were categorised accordingly.

\section{FINDINGS}

In this section, I will first present a general overview of findings, and then provide and discuss some exemplifications of tasks and activities. In general, we can say that at least one activity was found in the textbooks under examination for all the categories above; however, three course-books did not include any reference or task related to the development of CSs.

The first macro-area, appeal for help, includes 4 examples, almost equally distributed in the three periods under examination. As far as area (2) is concerned, meaning negotiation, is concerned, 9 course-books include activities of requests for repetition or clarification, with 3 occurrences for materials published in the 1990s, 11 in the 2000s and 4 in 2011-2015, with a total of 18 instances; as to confirmation checks, only 3 exemplifications were found in three different course-books, one for each period. In area (3), that of responses, we have 9 examples in 8 textbooks, mostly in the 2000s and 2010-2015 materials; we also have 2 instances for fillers and one for time-gaining (e.g. well, actually...; you know...; erm, let me see...). Finally, area (4), the one related to achievement strategies, presents eleven examples of activities in 7 textbooks, half of which published in the 2000s; CSs that are dealt with include paraphrase/circumlocution (6), approximation (2), description (3), using synonyms (1), and non-verbal moves (1).

Overall, the findings show that in my data CSs are not dealt with in a systematic way, apart from two textbooks (Ch, $\mathrm{NCh}^{4}, 1990$ s group) that have a specifically-dedicated

\footnotetext{
${ }^{4}$ Cf. Appendix 1 for course-books coding.
} 
section. Generally, when CS are included, few or no examples for contextualized language use are present, and little opportunity for practice is provided.

Particularly in the materials published until 2010, CSs activities are frequently presented in sections dedicated to Study Skills ('study strategies/help/skills'), and in most recent materials they are often mentioned (briefly) in the language skills sections, or as part of reflections on language awareness. This can partly be related to the fact that, above all in the 1990s, research on learning strategies often considered the latter as potentially contributing to the development of strategic competence, and compensation strategies in particular were seen in some studies as part of language learning strategies (OXFORD, 1990; O' MALLEY; CHAMOT, 1990; cf. also ELLIS, 2008). Although CSs are functionally different, with other sets of strategies in a language use orientation, " $t]$ he use of communication strategies may, indeed, lead to learning as the skilful learner exploits CS to elicit more input" (FAUCETTE, 2001, p. 4), with some overlapping areas, also in training terms (DÖRNYEI, 1995). In this perspective, in the course-books under examination, for example, a possible connection with CSs could have been fostered between strategies specifically related to listening skills, such as listening for gist or for specific information and communication in interaction, both in terms of awarenessraising and of 'reflective practice'.

\subsection{HOW ARE COMMUNICATION STRATEGIES PRESENTED? EXAMPLES FROM TEXTBOOKS}

In this section, examples of how CSs have been dealt with for each macro-area of investigation in the data under examination will be illustrated and discussed.

\subsubsection{Appeal for help}

The following example comes from the specific and regular section on Communication Strategies in the Intermediate Volume (Book 3) of NCh, published in 1996 (see Appendix 1). To be noticed that in the previous edition of the course-book (Ch, 1991), Volume 1 contained a brief section at the end of each unit, presenting useful expressions to be employed as CSs on topics such as asking for confirmation and clarification, using approximation and synonyms, how to interrupt someone in a conversation and attract his/her attention, how to gain time in a conversation while looking for an appropriate word or expression. As to Volume 3, while in the previous edition a section on CSs was placed at the end of each unit ${ }^{5}$, in NCh we find this section at the end of the volume. Five different topics are developed: Greetings and leave-taking - Opening and closing a conversation; Keeping a conversation going - Showing interest - Encouraging someone to talk; Getting help from the speaker; Adjusting the message -

5 The Volume in its previous edition (Ch) included also Expressing feelings and attitudes; Handling a topic: initiating, developing, concluding discourse. 
using approximations; Discussion techniques. Each topic is introduced by a reflection exercise to be carried out individually or in pairs/small groups, one or more listening passages where students are asked to identify the expressions and CSs that are introduced in the section, a matching exercise (question/response, function of CSs/language expression) and a freer practice activity. The Teacher's Book introduction specifies that these sections "aim at providing students with language awareness activities in which they can discover, analyse and practise in an explicit and systematic way strategies for coping with oral communication when linguistic resources are limited, i.e. when there is a gap between students' communicative intention and their linguistic competence". Each strategies section should be introduced "showing its relevance to communication problems that may arise in learning and using a foreign language" (TB NCh Intermediate, p. 10, italics in original). Despite the focus on the 'learner' - quite understandably since it is an ELT course-book - and on 'limited linguistic resources', this course-book still represents one of the very few examples in my dataset where CSs are treated in a systematic matter, which is also notable given that it belongs to the first group (1990s).

The section exemplified here is titled "Getting help from the speaker", where under 'appeal for help' we find also examples of circumlocution for specific lexical items, and of confirmation checks both on the listener's and the speaker's side; we can thus say there is a broader conception of asking for help in interaction and setting emphasis on the active role of both speaker and listener (see below).

The opening exercise in the section asks learners to work in pairs and think of what they would do and say in the following situations while talking to an English friend, and then share their answers:

1. You haven't understood what he/she has just said;

2. You can't follow her/him because he/she's talking too fast;

3. You aren't sure if you have understood correctly;

4. You would like to make sure that he/she has understood you (NCh Intermediate, 1996, p. 139).

In the Teacher's Book's suggested procedures we read that

this introductory activity should help make students aware that it is possible, indeed desirable, to take an active part in a conversation even when it is difficult to follow what the other person is saying, Strategies to get help from the speaker include, not just asking for help directly, but also [...] checking that one has understood and checking that the other person has understood. At the start of the lesson it is important that students should pool their resources and appreciate the fact that it is worth trying to do and say something even with a minimum of linguistic resources" (TB NCh Intermediate, p. 75, italics in original).

This first activity hence acts as a brainstorming session, contributing to draw attention on, and raise awareness of, the relevance of the speaker's and in the listener's cooperative attitudes in meaning co-construction. A listening comprehension exercise 
then follows, with a specific focus on noticing the expressions used in three short dialogues for description and circumlocution, and with the explanation of the Italian word 'ferragosto' in the third. As we read in the Teacher's Book, these recordings are meant to "provide examples of contextualized use of strategies" (TB NCh Intermediate, p. 10, italics in original).

In the following activity students are asked to identify in three groups of given expressions the ones that are related to asking "for help when you don't understand" (e.g. "Sorry, what did you say?"), checking "that you have understood" (e.g. "Does that mean...", "Do you mean...") and "that the other person has understood you" (e.g. "Do you see what I mean?”) (NCh Intermediate, p. 139). Students should then use these expressions in some given situations, and in the last freer practice exercise they work in pairs and describe details of a few given signs that are unclear, making sure the partner understands.

It should be mentioned that the Teacher's Book Introduction specifies that "the recordings often show how native speakers or 'good' language learners cope with the same situation students have just engaged in" (TB NCh Intermediate, p. 10). Despite the reference to the 'native speaker' (that can be inferred in the reference to 'English friend' in the first activity, too, see also 5.1.4), which still remains prevalent in ELT materials more than 20 years after the publication of this textbook, the fact that the 'good' language learner is mentioned can be considered a step forward in moving away from a NS perspective.

One further point that is relevant in pedagogic terms is the explicit reference that is made in the Teacher's Book to the fact that "in order to help students maintain the strategies in time, transfer them to new situations and activate them in an autonomous way, it is essential that once they have been explicitly introduced and practised, the teacher should remind students of them and prompt and encourage their use in subsequent everyday tasks" (TB NCh Intermediate, p. 10, italics in original). This draws the attention on the importance of overtly introducing first noticing (intended as drawing attention to and fostering awareness of certain linguistic forms, e.g. SCHMIDT 1990, 2001), and then practice activities on CSs. It also points to the fact that CSs should be considered as a transversal aspect and an underlying set of tools in a communicative-oriented approach to in language teaching and learning. Research findings in ELF communication have clearly highlighted the relevance of CSs in these international settings, which further confirms the importance of introducing them in ELT practices in a consistent way. Together with the promotion of awareness of active listening and participation in the mutual co-construction of meaning highlighted above, these aspects make the activities exemplified here a valuable starting point for the development of CSs-oriented classroom practices.

\subsubsection{Confirmation checks}

As seen above, this area was investigated by categorising findings into two sub-sections: 
(a) meaning negotiation: requests for repetition, clarification, direct questions/minimal queries;

(b) meaning negotiation: confirmation checks, direct/indirect question, repetition in rising intonation, interpretative summary (e.g. you mean...?), content summary.

In general, the material under examination tends to present examples of language expressions related to area (a) above, with only two instances for area (b) (cf. VETTOREL, 2018). Generally, examples to express non-understanding or to ask for repetition are provided in lists, with little or no contextualised practice. The following instances exemplify this trend in the data; they are part of the separate booklet of $\mathrm{N}(2000$, specifically related to preparation for the international Trinity Grade examinations in spoken English. In general, this course-book does not contain specific sections or references to CSs, neither in the student's materials nor in the Teacher's Guide; regular sections on study skills are instead included in each teaching unit, generally in the form of 'Tips' and 'Task' for areas such as vocabulary learning, using a dictionary, writing different types of texts, taking notes, etc. The exam booklet is dedicated to strategies and suggestions 'for the exam'; it is organized into different 'grades', each linked to the coursebook modules. The following examples, all related to requests for clarification, can be found in three different grades (1,5 and 6):

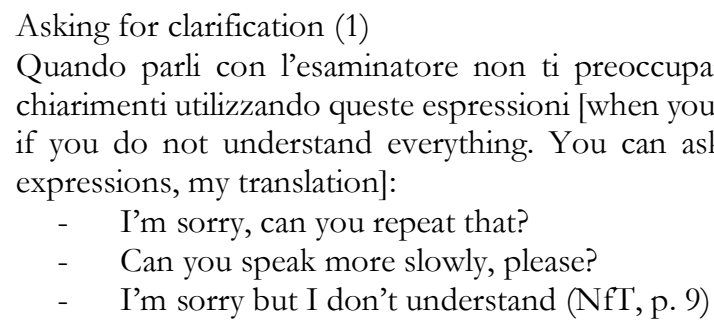
expressions, my translation]:

- I'm sorry, can you repeat that?

- Can you speak more slowly, please?

- I'm sorry but I don't understand (NfT, p. 9) chiarimenti utilizzando queste espressioni [when you are talking to the examiner, don't worry if you do not understand everything. You can ask for clarifications using the following

Asking for clarification (2)

Se non hai capito qualcosa, puoi dire [if you don’t understand something, you can say, my translation]:

- Sorry, I don't really follow you.

- $\quad$ Sorry, could you say that again please? (NfT, p. 29)

Asking for clarification (3)

Se non hai capito, puoi dire [if you don't understand, you can say, my translation]:

Sorry, I missed that.

- Sorry, I didn't get that (NfT, p. 33)

Apart from a general suggestion to employ these language expressions as frequently as possible in other tasks, no further guided or freer practice activities are presented, despite the reference to 'A short course to build up communication skills' in the booklet subtitle. They thus seem to constitute 'useful formulaic language', that is in this case 
proposed only in connection to the context of the exam, with no reference to how the expressions may be fruitfully employed in more general contexts and in contextualised interaction.

\subsubsection{Responses - repetition, rephrasing, expansion, reduction/simplification, confirmation, rejection, repair; lexical anticipation / suggestion / correction; use of fillers and time-gaining devices)}

In Area 4 we find several instances that are generally inserted under headings such as 'speaking strategies' (C) or 'keeping the conversation going/showing interest (NCh, OnT, $\mathrm{F} 2 \mathrm{~F}, \mathrm{NfT}$ ), in two cases with reference to useful techniques for exams (NfT, On'T). One example of the latter in terms of introductory language formulae for reformulation techniques is the following, which is presented under the 'Saying it differently' section:

Ecco delle espressioni che puoi usare quando ti sembra che l'esaminatore non abbia capito [Here are some expressions you can use when you think the examiner has not understood, my translation]:

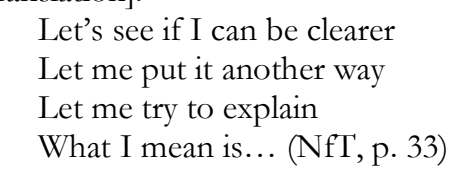

As in the examples in the previous section, CSs are here associated only to exam preparation, with specific reference to international certifications. These instances, as well as other CSs that are included in the booklet such as meaning negotiation requests and confirmation are widely used in real-life interaction, and particularly in ELF; it would thus seem important to connect their use to more general and broader communicative contexts.

Both this list and the ones discussed in the previous section are not accompanied by reflection or practice activities, and suggestions on how to rephrase, expand or confirm the message are not included. Once again, CSs that have been shown to be widely used by speakers in international communication contexts seem to be dealt with in an unsystematic and limited way in the data under examination, not providing learners with tools that would enable them to cooperatively interact through the foreign language in broader, 'real-life' communication contexts.

\subsubsection{Achievement strategies: circumlocution/paraphrase, approximation/all- purpose words/word-replacement, restructuring, word-coinage, code- switching (literal translation from $\mathrm{L} 1 / \mathrm{Ln}$, foreignizing, code-switching L1/L3/Ln)}

The last area of investigation is quite widely represented when compared to the previous ones, and CSs that are dealt with include paraphrase/circumlocution (6), 
approximation (2), description (3), using synonyms (1), and non-verbal moves (1). As to code-switching, we find only one example related to requests for clarification ('Check that you understand'), with two lexical items in Turkish in a dialogue at a restaurant:

Can you explain what 'beying tavasi' is?, What does 'ordövr' mean?” (CE Pre-Intermediate, p. 63)

In other cases, more general 'How do you say ... in English?' are provided; since these are frequently included in 'classroom language sections' (e.g. EF), their reference is likely to be to the students' L1, Italian (see below).

One example that comes under the heading 'Describing objects and asking questions' in the regular section 'Talking tips' of another course-book (YCh) is the following:

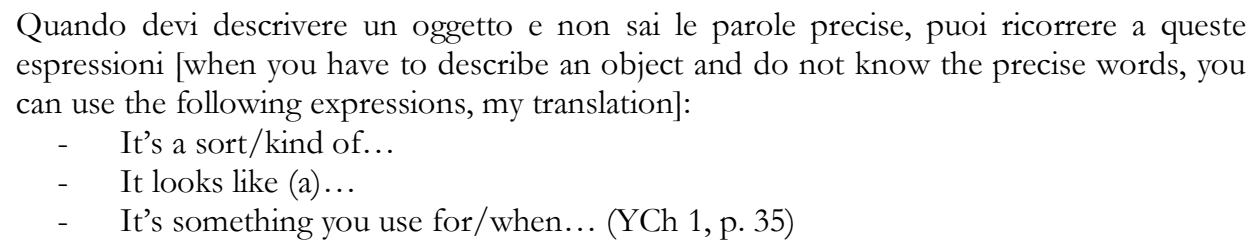

In this textbook, together with sections on skills, strategies and 'learning to learn', a 'Talking tips' section is present in all units; besides references to language functions, at times suggestions on useful language to interact in conversations are included, too, as in the 'Talking bits' one; related activities are generally included also in the Workbook. As to the example above, we read in the Teacher's Guide that "the aim of the activity is to develop fluency and compensatory strategies, that is, ways to overcome difficulties when one does not know a specific word" (TG YCh, p. 39); with reference to the freer practice activity (describing an object) students should be encouraged "to use all the language they know. If they need new vocabulary, encourage them to ask for help in English: What's the English for...? How do you say (...) in English?” (TG YCh, p. 43). Further practice is then provided in the freer practice activities, particularly in the 'Your challenge' section, with tasks that are "aimed at developing fluency and communication strategies" (TG YCh, p. 16).

In terms of circumlocution/paraphrase, the example in this course-book can be said to constitute a good way to introduce students to this communication strategy in terms of effective communication, not least in the overt focus on language use and fluency.

Another positive exemplification can be found in the aforementioned Communication Strategies section of NCh Intermediate. In this case, the topic is introduced as "Adjusting the message - using approximations" (NCh Intermediate, p. 141). In the Teacher's Book we read that "this section deals with ways in which meaning can be expressed when the linguistic competence is not up to the standard that would be 
required for smooth encoding of the message, a situation which is typical of L2 users, but which is not uncommon even in L1" (TB NCh Intermediate, p. 76).

A noticing activity to be carried out in pairs opens the section in the Student's Book, followed by another similar task related to a recorded conversation on these same topics:

Suppose you were talking to an English friend in the following situations. What would you do and / or say to make yourself understood? Compare your answers in small groups:

1. You don't know the English word for 'comodino'.

2. You want to explain that your 'medico di famiglia' came to visit you yesterday.

3. Your friend has asked you what Italians mean by 'ferragosto'. (NCh Intermediate, p. 141)

The activity is followed by a task related to a recording; significant that, as pointed out in the Teacher's Book, attention should be drawn to the fact that

the woman in the recording is an Italian with reasonably good knowledge of English [...] the woman is not a teacher, nor has she had any specific training in this sort of activity: she is simply using her own intuitive strategies to cope with the gaps in her own competence (and also, to cope with the problem of expressing cultural concepts that have no exact equivalent in another language/culture). In this way, lead students to consider the fact that communication strategies are intuitive ways of using one's own linguistic and cultural resources, but that they can be refined and developed through observation and practice (TB NCh Intermediate, p. 77).

Two main points are worth highlighting here: first, that the recording features a non-native speaker with a "reasonably good knowledge of English" (cf. 5.1.1); secondly, the note specifying that, although CSs can be 'intuitively' transferred from L1 to L2/Ln both from a linguistic and a cultural point of view, their effective use in communication can be fostered through overt noticing and practice.

A matching exercise with some mini-dialogues containing expressions such as "What do you mean by..., what does ... mean?, you mean that....?, with what?, such as?", as well as an example of repetition and "Sorry?" as a minimal query are then introduced, followed by an inductive activity where students are asked to match the responses given with their function choosing from "using examples, using a definition or a description, using a synonym ( $=$ a word of the same or similar meaning), using an antonym ( $=$ a word opposite in meaning), paraphrasing (= re-expressing in other words), using words of more general meaning (e.g. flower instead of rose)" (ibid., italics in original).

In the next activity, students are asked to practise the use of synonyms, antonyms, examples and general words for some lexical items that are provided in Italian, and we then find a further noticing activity on a recorded description of some objects (TB NCh Intermediate, p. 142). Before moving on to other practice activities (description of objects to be identified and then used in freer conversation in pairs), a list of language expressions to define or describe items is provided, together with examples, for the following categories: general class, shape, size, colour, texture, material, structure, function and 
context (TB NCh Intermediate, p. 143); this list is meant "as a way to make students aware of the various possibilities that are open to them when they try to define or describe something or someone. At the same time, the list gives some examples of useful language that can be used for the purpose" (TB NCh Intermediate, p. 78). Students are then asked to write definitions or descriptions of some objects that are given in a picture (e.g. hammer, stair, wheelchair, colander, luggage rack) and then to compare them with the given dictionary definitions.

The last activity is once more a noticing one, where in three short conversations some words that have a specific cultural connotation are involved (foglio rosa/provisional driving licence, cassa integrazione - indennità di disoccupazione/redundancy with unemployment benefits, case popolari/council houses), a point that was also highlighted in the picture in the opening page of the section (Comando Vigili Urbani/headquarters of the municipal police). As in some of the previously described activities (cf. 5.1), in this textbook drawing attention on the use of CSs to express concepts that are linguaculturally specific can be particularly important in order to prepare learners to communicate in ELF contexts. These communicative settings are by definition characterised by the meeting of different lingua-cultures, and meaning is often mediated and co-constructed through an effective use of CSs, not least as to 'cultural concepts' (VETTOREL, 2017; PITZL 2017).

\section{CONCLUDING REMARKS AND IMPLICATIONS FOR ELT}

The object of this paper was to investigate whether, and how, Communication Strategies have been taken into account and dealt with in a set of Italian ELT coursebooks published from 1990 to 2015. Findings show that CSs have rarely been included in the materials under examination in a systematic and organized way, and even when they are taken into account, exemplifications of their use in context, as well as opportunities for practice, are provided only in a few cases. Even when references to CSs within a communicatively-oriented approach are openly declared in the Teacher's Guide/Book, a correspondence with activities and tasks is not always present, or consistently and adequately developed.

In addition, even where fruitful connections could have been established for example between the 'study skills' sections, particularly when focused on strategies aimed at supporting effective listening, and awareness of CSs use in interaction, this does not seem to be the case. The same can be said for 'speaking skills' sections, where CSs could be introduced through guided and freer practice activities, rather than only with lists of formulaic language expressions related to showing interest such as 'I see', 'really?', 'I know what you mean' and the like. The same can be said for sections and activities dealing with language functions, such as agreeing and disagreeing, that are present in the great majority of CLT-oriented course-books, or for more pragmatic language suggestions (e.g. how to interrupt someone politely) that are at times present (e.g. OnT, VE, OT): these would seem excellent opportunities to create 'natural' connections, and practice, for CSs to be first noticed and then practiced (cf. SEIDLHOFER 2003; COGO; PITZL 2016). 
Noticeable that several more recent textbooks make specific reference to 'not to worry about making mistakes', generally in connection to fluency (GT, U, C, VE, EiM); at times suggestions are also given - for example, "use gestures or mime if you can't think of a word you need. Don't stop speaking” (U, p. 159). However, once again there does not seem to be an integration between such remarks and a consistent attention to the development of CSs in actual language use.

Exemplifications of communication in ELF settings were not noticed in the data, in line with findings from research in this area (e.g. VETTOREL, LOPRIORE, 2013), not even in most recent materials. As mentioned in earlier sections of this paper, given the relevance of CSs, from repetition and clarification requests to paraphrase in ELF communication in meaning co-construction and achievement of mutual understanding, it would seem reasonable to make learners aware of such aspects in ELT materials. Providing exemplifications of how these expressions are used in context, as well as opportunities for guided and freer practice in (ELF) naturally occurring conversations, would seem equally important.

It should also be noted that communicative contexts for CSs are at times limited to 'classroom language' (e.g. EF, OT, OnT, EiM). In addition, although references to opportunities of practicing English in outside-school settings or resources are mentioned in several course-books (e.g. EF, JTT, SoY, EiM, GT, U), these are rather general and rarely exploited with 'active practice' tasks, or with examples of how CSs can effectively support communication and meaning co-construction.

The new contexts and roles in which English is largely used today, especially as a lingua franca, would instead call for a re-thinking of notions such as that of Communicative Competence in all its components (e.g. WIDDOWSON, 2003; LEUNG 2005; SEIDLHOFER 2011), and particularly of Strategic Competence as "the ability to generate many alternative ways of saying something” (TARONE, 2016, p. 219). In pedagogical terms, As Cogo and Dewey point out (2012, p. 176, cf. also SEIDLHOFER, 2011; WIDDOWSON 2012, 2015),

teachers and learners need to become more aware of the role of accommodation skills in effective intercultural communication. In our view, it would be highly beneficial if ELT professionals were to shift their emphasis in terms of the way language competence is understood - it is a speaker's flexibility to accommodate that ensures effective intercultural communication not proximity to a fixed set of grammatical norms.

As we have seen, some of the course-books examined in this paper do include activities aimed at fostering CSs didactic practices. These positive exemplifications, together with other pedagogically oriented proposals (e.g. DÖRNYEI; THURREL, 1991; MARIANI, 2010; VETTOREL 2010; LOPRIORE; VETTOREL, forthcoming) could constitute a starting point for the development of ELF-aware materials to be experimented by teachers, teacher educators and ELT material developers. As Kohn (2016, p. 28) argues, 
Suitable tasks should be designed around authentic ELF communication with a focus on meaning and community-related communicative intentions, the identification and analysis of problems, and the exploitation of strategic solutions. Relevant back-up support is provided by reflective followup and complementary learning about activities.

Although not generalizable given the relatively small dataset and the fact that it refers specifically to the Italian context, the findings in this study can nevertheless provide insights into this area of research. Further investigation on the ways in which CSs are dealt with in ELT course-books from an ELF-aware perspective and, more generally, on the pedagogical implications of findings on CSs from ELF, could contribute first to raise awareness of the relevance of focusing on Strategic Competence in pedagogical terms, and consequently lead towards the development of adequate materials and activities by teachers, teacher educators and publishers.

\section{REFERENCES}

BATZIAKAS, B. Communicative practices in English as a lingua franca interactions: some examples from Asian university students in London. Asian Englishes, n.19, v.1, p. 44-56, 2017.

BJØRGE, A. K. Conflict or cooperation: The use of backchannelling in ELF negotiation. English for Specific Purposes, v. 29, n.3, p. 191-203, 2010.

BJÖRKMAN, B. Pragmatic strategies in English as an academic Lingua Franca: ways of achieving communicative effectiveness?. Journal of Pragmatics, v. 43, n. 4, p. 950-964, 2011.

BJÖRKMAN, B. An analysis of polyadic English as a lingua franca (ELF) speech; a communicative strategies framework. Journal of Pragmatics, v. 66, p. 122-138, 2014.

BIALYSTOK, E. Communication strategies. Oxford: Blackwell, 1990.

CANALE, M. From Communicative competence to communicative language teaching. In: RICHARDS, J.C.; SCHMIDT, R.W. (Eds.). Language and communication. London: Longman, 1983. p. 2-27.

CANALE, M., SWAIN, M. Theoretical bases of communicative approaches to second language teaching and testing. Applied Linguistics, v. 1, p. 1-47, 1980.

CELCE-MURCIA, M., DÖRNYEI, Z., THURREL, S. Communicative Competence: a pedagogically motivated model with context specification. Issues in Applied Linguistics, v. 6, n. 2, p. 5-35, 1995. 
COGO, A. Accommodating difference in ELF conversations: a study of pragmatic strategies. In: MAURANEN, A.; RANTA, E. (Eds.). English as a Lingua Franca: studies and findings.. Newcastle upon Tyne: Cambridge Scholars Publishing, 2009. p. 254-273.

COGO, A. Strategic use and perceptions of English as a lingua franca. Poznań Studies in Contemporary Linguistics, v. 46, n. 3. p. 295-312, 2010.

COGO, A. ELF and Super-diversity: a case study of ELF: Multilingual practices from a business context. Journal of English as a Lingua Franca, v. 1, n. 2, p. 287-313, 2012.

COGO, A. 'They all take the risk and make the effort': Intercultural accommodation and multilingualism in a BELF community of practice. In: LOPRIORE, L; GRAZZI, E. (Eds.). Intercultural communication. New perspectives from ELF. Rome: Roma TrE-Press, 2016. p. 365-383.

COGO, A. ELF and multilingualism. In: JENKINS, J.; BAKER, W.; DEWEY, M. (Eds.). The Routledge Handbook of English as a Lingua Franca. Abingdon: Routledge, 2018, 357-368.

COGO, A., DEWEY, M. Analysing English as a lingua franca. London/New York: Continuum, 2012.

COGO, A., PITZL, M.-L. Pre-empting and signalling non-understanding in ELF. ELT Journal, v. 70, n. 3, p. 339-345, 2016.

COHEN, A.D., MACARO, E. (Eds.). Language learner strategies. Oxford: Oxford University Press. 2007.

DÖRNYEI, Z. On the teachability of communication strategies. TESOL Quarterly, v. 29, n. 1, p. 55-85, 1995.

DÖRNYEI, Z., SCOTT, M. L. Communication strategies in a second language: definitions and taxonomies. Language Learning, v. 47, n. 1, p. 173-210, 1997.

DÖRNYEI, Z., THURREL, S. Strategic competence and how to teach it. ELT Journal, v. 45, n.1, p. 16-23, 1991,

DÖRNYEI, Z., THURREL, S. Teaching conversational skills intensively: course content and rationale. ELT Journal, v. 48, n. 1, p. 40-49, 1994;

ELLIS, R. Understanding second language acquisition. Oxford: Oxford University Press, 1985.

ELLIS, R. The study of second language acquisition. Oxford: Oxford University Press, 2008 (2 ${ }^{\text {nd }}$ edn.).

FAUCETTE, P. A pedagogical perspective on communication strategies: benefits of training and an analysis of English language teaching materials. Second Language Studies, v. 19, n. 2, p. 1-40, 2001.

FIRTH, A., WAGNER, J. On discourse, communication, and (some) fundamental concept in SLA research. The Modern Language Journal, v. 91, p. 757-772, [1997] 2007. 
FRANCESCHI, V. Plurilingual resources as an asset in ELF business interactions. Journal of English as a Lingua Franca, v. 6, n. 1, p. 57-81, 2017.

GARCÍA, O.; WEI L. Translanguaging; Language, bilingualism and education. London: Palgrave Macmillan, 2014.

JAFARI, J. Communication strategies in English as a Lingua Franca interactions: a study of university Students. Presentation given at ELF9 Conference, Lleida, 27-29 June 2016.

JAFARI, J. Communication strategies among ELF interlocutors in international contexts: a study of university students, presentation given at ELF10 Conference ELF \& Changing English, Helsinki, 12-15 June 2017.

JENKINS, J. Repositioning English and multilingualism in English as a lingua franca. Englishes in Practice, v. 2, n. 3, p. 49-85, 2015.

JOKIĆ, N. Did we get our wires crossed? The analysis of communication strategies among Erasmus students. Presentation given at ELF9 Conference, Lleida, 27-29 June 2016.

JØRGENSEN, J. N. 2008. Introduction. Polylingual languaging around and among children and adolescents. International Journal of Multilingualism, v. 5, n. 3, p. 161-176, 2008.

KALOCSAI, K. Communities of practice and English as a Lingua Franca. Berlin: Mouton de Gruyter, 2013.

KAUR, J. English as a Lingua Franca: Co-constructing understanding. Saarbrucken: VDM Verlag, 2009.

KELLERMAN, E. Compensatory strategies in second language research: a critique, a revision, and some (non-)implications for the classroom. In PHILLIPSON, R.; KELLERMAN, E.; SELINKER, L.; SHARWOOD SMITH, M.; SWAIN, M. (Eds.), Foreign/ second language pedagogy research. Clevedon: Multilingual Matters, 1991, p. 142-161.

KIM, Y. Communication strategies in seventh grade English textbooks. English Teaching, v. 65, n. 1, p. 113-136, 2010.

KIRKPATRIK, A. The communicative strategies of ASEAN speakers of English as a lingua franca. In: PRESCOTT, D. (Ed.), English in southeast Asia: Varieties, literacies and literatures. Newcastle-upon-Tyne: Cambridge Scholars, 2007. p. 118-137.

KLIMPFINGER, T. 2007. Mind you sometimes you have to mix - the role of codeswitching in English as a lingua franca. Vienna English Working PaperS, v. 16, n. 2, p. 36-61, 2007.

KLIMPFINGER, T. 2009. "She's mixing the two languages together" - Forms and functions of Code-switching in English as a Lingua Franca. In: MAURANEN, A.; RANTA, E. (Eds.), English as a lingua franca: studies and findings. Newcastle-upon-Tyne: Cambridge Scholars, 2009. p. 349-371. 
KOHN, K. 2016. Teaching towards ELF competence. In: TSANTILA, N.; MANDALIOS, J.; ILKOS, M. (Eds.). ELF: Pedagogical and interdisciplinary perspectives. Athens: Deree-The American College of Greece, 2016. p. 25-32.

KONAKAHARA, M. Reconsideration of communication strategies from an English as a lingua franca perspective. Bulletin of the Graduate School of Education of W aseda University, v. 20, n. 1, 2012, p. 201-216.

LEUNG, C. Convivial communication: recontextualizing communicative competence. International Journal of Applied Linguistics v. 15, n. 2, p. 119-144, 2005.

LOPRIORE, L., VETTOREL, P. Perspectives in WE and ELF-oriented ELT materials in teacher education. In SIFAKIS, N.; TSANTILA, N. (Eds.), ELF4ELF. Clevedon: Multilingual Matters, forthcoming.

MAURANEN, A. Signalling and preventing misunderstanding in English as a lingua franca communication. International Journal of the Sociology of Language, v. 177, p. 123-150, 2006.

MARIANI, L. Communication strategies. Milan: Tante Vie per Imparare, 2010.

MAURANEN, A. 2007. Hybrid voices: English as the lingua franca of academics. In: FLOT'TUM, K. (Ed.). Language and discipline perspectives on Academic Discourse. Newcastleupon-Tyne: Cambridge Scholars, 2007. p. 243-259.

MAURANEN, A. Exploring ELF. Academic English shaped by non-native speakers. Cambridge: Cambridge University Press, 2012.

MCCONACHY, T., HATA, K.. Addressing textbook representations of pragmatics and culture. ELT Journal , v. 67, n. 3, p. 294-301, 2013.

MEIHAMI, H., KHANLARZADEH, M. Pragmatic content in global and local ELT textbooks: a micro analysis study. SAGE Open, p. 1-10, 2015.

OLLINGER, A. The good ELF user: a qualitative meta-analysis of strategic language use behaviours in English as a Lingua Franca. Masterarbeit, University of Vienna, 2012.

O’ MALLEY, J.M., CHAMOT, A.U. Learning strategies in Second Language Acquisition. Cambridge: Cambridge University Press, 1990.

OXFORD, R. Language learning strategies: What every teacher should know. New York: Newbury House, 1990.

PITZL, M.-L. English as a lingua franca in international business. Resolving miscommunication and reaching shared understanding. Saarbrücken: VDM-Verlag Müller, 2010.

PITZL, M.-L. Creativity and re-metaphorised idioms in spoken ELF interactions. Presentation given at the English as a Lingua Franca International Symposium, Sapienza University, Rome, 6-7 April 2017. 
RAMPTON, B. A sociolinguistic perspective on communication strategies. In: KASPER, G.; KELLERMAN, E. (Eds.). Communication strategies: Psycholinguistic and sociolinguistic perspectives, 279-303. London/New York: Longman, 1997. p. 279-303.

REN, W., HAN Z. The representation of pragmatic knowledge in recent ELT textbooks. ELT Journal, v. 70, n. 4, p. 424-434, 2016.

RICHARDS, J. The role of textbooks in a language program. New Routes, v. 17, p 26-30, 2002. São Paulo: DISAL.

SAVIGNON, S. Communicative competence: an experiment in foreign language teaching. Philadelphia: Center for Curriculum Development, 1972.

SAVIGNON, S. Communicative competence. Theory and practice. New York: McGraw-Hill, 1997 ( $2^{\text {nd }}$ edn.).

SCHMIDT, R. The role of consciousness in second language learning. Applied Linguistics, v. 11, p. 129-158, 1990.

SCHMIDT, R. Attention. In: ROBINSON, P. (Ed.), Cognition and second language instruction . Cambridge: Cambridge University Press, 2001. p. 3-32.

Cambridge, UK: Cambridge University Press.

SEIDLHOFER, B. Research perspectives on teaching English as a lingua franca. Annual Review of Applied Linguistics, v. 24, p. 209-239, 2004.

SEIDLHOFER, B. Understanding English as a Lingua Franca. Oxford: Oxford University Press, 2011.

SEIDLHOFER B. English as a Lingua Franca and multilingualism. In: CENOZ, J.; GORTER, D.; MAY, S. (Eds.). Language awareness and multilingualism, Encyclopedia of Language and Education. Cham: Springer, 2015. p. 1-14.

SIQUEIRA, D. S. P. English as a Lingua Franca and ELT materials: is the 'plastic world' really melting? In: BAYYURT, Y.; AKCAN, S. (Eds.). Current perspectives on pedagogy for English as a Lingua Franca. Berlin: Mouton de Gruyter, 2015. p. 239-258.

TARONE, E. Communication strategies, foreigner talk and repair in interlanguage. Language Learning, v. 30, n. 2, p. 417-431, 1980.

TARONE, E. Some thoughts on the notion of communication strategies. TESOL Quarterly, v. 15, n. 3, p. 285-295, 1981.

TARONE, E. (1984). Teaching strategic competence in the foreign language classroom. In: SAVIGNON, S.; BERNS, M. (Eds.), Initiatives in Communicative Language Teaching. Reading, MA: Addison Wesley, 1984. p. 127-136. 
TARONE, E. 2016, Learner language in ELF and SLA. In: PITZL, M.-L.; OSIMKTEASDALE, R. (Eds.) English as a Lingua Franca: Perspectives and prospects. Berlin: Mouton de Gruyter, 2016, 217-225.

TARONE, E., YULE, G. Focus on the Language Learner. Oxford: Oxford University Press, 1989.

VETTOREL, P. Strategie comunicative, plurilinguismo e ELF. Lend Lingua e Nuova Didattica, Anno XXXIX, v.3. p. 13-23, 2010.

VETTOREL, P. Communication Strategies and co-construction of meaning in ELF Communication: drawing on 'Multilingual Resource Pools', presentation given at ELF10 Conference ELF \& Changing English, Helsinki, 12-15 June 2017.

VETTOREL, P. ELF and communication strategies: are they taken into account in ELT materials? RELC Special Issue on 'Teaching English as an International Language (TEIL): realistic or idealistic?, guest Ed. MARLINA, R. p. 1-16, 2018.

VETTOREL, P., LOPRIORE, L. Is there ELF in ELT course-books? Studies in Second Language Learning and Teaching, v. 4, n. 3, p. 483-504, 2013.

WAGNER, J., FIRTH, A. Communication strategies at work. In: KASPER, G.; KELLERMAN, E. (Eds.) Communication strategies: Psycholinguistic and sociolinguistic perspectives. London/New York: Longman, 1997. p. 322-344.

WATTERSON, M. Repair of non-understanding in English in international communication. World Englishes, v. 27, n. 3, p. 378-406, 2008.

WIDDOWSON H. Learning purpose and language use. Oxford: Oxford University Press, 1983.

WIDDOWSON, H. Defining issues in English language teaching. Oxford: Oxford University Press, 2003.

WIDDOWSON, H. Afterword. Frontiers of English and the challenge of change. In VETTOREL, P. (Ed.) New Frontiers in teaching and learning English, Newcastle-upon-Tyne: Cambridge Scholars, p. 227-232.

YOSHIDA, K. The fish bowl, open seas, and international English. In Expanding Horizons: Techniques and Technology in ELT. Proceedings of the 12th Annual KOTESOL International Conference, Seoul: Korea TESOL, 2004, p. 11-20.

YU, M. H. Developing critical classroom practice for ELF communication: a Taiwanese case study of ELT materials evaluation. In: BOWLES, H.; COGO, A. (Eds.). International perspectives on English as a Lingua Franca. Pedagogical insights. Basingstoke: Palgrave Macmillan, 2015, p. 35-54. 


\section{Appendix 1}

Course-books examined

\begin{tabular}{|c|c|c|c|}
\hline Authors & $\begin{array}{l}\text { Title } \\
\text { (reference } \\
\text { acronym) }\end{array}$ & $\begin{array}{l}\text { Publication } \\
\text { Year }\end{array}$ & Publisher \\
\hline \multicolumn{4}{|l|}{$1990-1999$} \\
\hline $\begin{array}{l}\text { MARIANI, L., O’ MALLEY, K. } \\
\text { MARIANI, L. Vol.3 }\end{array}$ & $\begin{array}{l}\text { Choices } \\
(\mathrm{Ch})\end{array}$ & 1991 & Zanichelli \\
\hline $\begin{array}{l}\text { OXENDEN, C.; SELIGSON, P. SB1 } \\
\text { with FOLEY, M. WB1 } \\
\text { OXENDEN, C.; SELIGSON, P.; } \\
\text { LATHAM-KOENIG, C. SB2, WB2 }\end{array}$ & $\begin{array}{l}\text { English Files } \\
\text { (EF) }\end{array}$ & $\begin{array}{l}1996 \\
2002\end{array}$ & $\begin{array}{l}\text { Oxford University } \\
\text { Press }\end{array}$ \\
\hline $\begin{array}{l}\text { MARIANI, L.; O’ MALLEY, K. } \\
\text { MARIANI, L. VOL. } 3\end{array}$ & $\begin{array}{l}\text { New Choices } \\
\text { (NCh) }\end{array}$ & 1996 & Zanichelli \\
\hline SIMON GREENALL & $\begin{array}{l}\text { Reward } \\
(\mathrm{R})\end{array}$ & 1997 & Heinemann \\
\hline PAPA, M.; SHELLEY, J. & $\begin{array}{l}\text { Just take turns } \\
\text { (JTT) }\end{array}$ & $1998 / 99$ & Zanichelli \\
\hline \multicolumn{4}{|l|}{$2000-2009$} \\
\hline $\begin{array}{l}\text { CUMINO, M. } \\
\text { LOWES, R.; TARGET, F. (ED. } \\
\text { CUMINO, M.) }\end{array}$ & $\begin{array}{l}\text { Now } \\
\text { (N) } \\
\text { Now for Trinity } \\
\text { (NfT) }\end{array}$ & $\begin{array}{l}2000 \\
2001\end{array}$ & $\begin{array}{l}\text { Oxford - La Nuova } \\
\text { Italia }\end{array}$ \\
\hline CUNNINGHAM,S.; MOOR, P. & $\begin{array}{l}\text { Cutting Edge } \\
\text { (CE) }\end{array}$ & 2001 & Longman \\
\hline MARIANI, L.; O’ MALLEY, K. & $\begin{array}{l}\text { On Target } \\
(\mathrm{OT})\end{array}$ & $2002 / 2003$ & Zsanichelli \\
\hline $\begin{array}{l}\text { PAVONI, M.; POZZO, G.; with } \\
\text { PAGE-MILETTO, H.; MINERVA, R. }\end{array}$ & $\begin{array}{l}\text { Your Challenge } \\
\text { (YCh) }\end{array}$ & 2003 & Loescher \\
\hline RADLEY,P.; SIMONETTI, D. & $\begin{array}{l}\text { Horizons } \\
(\mathrm{H})\end{array}$ & 2003 & $\begin{array}{l}\text { Oxford University } \\
\text { Press - La Nuova } \\
\text { Italia }\end{array}$ \\
\hline $\begin{array}{l}\text { PUCHTA, H.; STRANKS, J. } \\
\text { with LEVY, M; DEL LUNGO, A. SB1, } \\
\text { WB1 } \\
\text { THACKER, C.; PELTERET, C.; with } \\
\text { PUCHTA, H.; STRANKS, J.; DEL } \\
\text { LUNGO, A. TG1 } \\
\text { THACKER, C.; with PUCHTA, H.; } \\
\text { STRANKS, J.; DEL LUNGO, A. TG2 }\end{array}$ & $\begin{array}{l}\text { English in } \\
\text { Mind } \\
\text { (EiM) }\end{array}$ & 2004 & $\begin{array}{l}\text { Cambridge } \\
\text { University } \\
\text { Press/Loescher }\end{array}$ \\
\hline PAPA, M.; SHELLEY, J. & $\begin{array}{l}\text { Spotlight on } \\
\text { you } \\
\text { (SoY) }\end{array}$ & 2005 & Zanichelli \\
\hline MARCELLI, C.; WOOD, T. & $\begin{array}{l}\text { Solutions } \\
\text { (S) }\end{array}$ & 2005 & Longman \\
\hline $\begin{array}{l}\text { O’ MALLEY, K.; TULIP, M.; in } \\
\text { collaboration with MARIANI, L. }\end{array}$ & $\begin{array}{l}\text { On Track } \\
(\text { OnT })\end{array}$ & 2006 & Zanichelli \\
\hline $2010-2015$ & & & \\
\hline
\end{tabular}




\begin{tabular}{|c|c|c|c|}
\hline $\begin{array}{l}\text { FREEBAIRN, I.; BYGRAVE, J.; } \\
\text { COPAGE, J.; with SCORNITO, B.; } \\
\text { TORCHIA, F. } \\
\text { MUGGLESTONE, P.; FUSCOE, K.; } \\
\text { FREEBAIRN, I.; BYGRAVE, J.; } \\
\text { COPAGE, J. TB }\end{array}$ & $\begin{array}{l}\text { Upbeat } \\
\text { (U) }\end{array}$ & 2010 & Pearson Longman \\
\hline $\begin{array}{l}\text { LOPRIORE, L.; CERUTI, M. } \\
\text { LOPRIORE, L.; CERUTI, M.; } \\
\text { with BOYLE, B.A. SB }\end{array}$ & $\begin{array}{l}\text { Voicing English } \\
\text { (VE) }\end{array}$ & 2010 & Loescher \\
\hline SHELLEY, J. & $\begin{array}{l}\text { My Life } \\
\text { (Multimedia } \\
\text { edition) } \\
\text { (ML) }\end{array}$ & 2012 & Zanichelli \\
\hline $\begin{array}{l}\text { REDSTON, C.; CUNNINGHAM, G. } \\
\text { TIMS, N., with REDSTON, C.; } \\
\text { CUNNINGHAM, G. WB B1 }\end{array}$ & $\begin{array}{l}\text { face } 2 \text { face }(2 \mathrm{nd} \\
\text { edn) } \\
(\mathrm{F} 2 \mathrm{~F})\end{array}$ & $2012 / 2013$ & $\begin{array}{l}\text { Cambridge } \\
\text { University Press }\end{array}$ \\
\hline $\begin{array}{l}\text { THOMAS, A.; GREENWOOD, A.; } \\
\text { HEWARD, V.; MINARDI , S. (VOL.1) } \\
\text { O’DELL, F.: BERBERO, M.; } \\
\text { HEWERD, V.; MINARDI, S. (VOL. 2) } \\
\text { BROADHEAD, A.; LIGHT, G.; } \\
\text { KELLY CALZINI, M.; SEITA, A.; } \\
\text { HEWERD, V.; MINARDI, S. (VOL. 3- } \\
\text { B2) } \\
\text { THOMAS, A.; O’DELL, F.; } \\
\text { GREENWOOD, A.; BARBERO, M.; } \\
\text { HEWARD, V.; MINARDI, S.; } \\
\text { BROOM , N. (TB) }\end{array}$ & $\begin{array}{l}\text { Cult } \\
\text { (C) }\end{array}$ & 2015 & $\begin{array}{l}\text { Black Cat /DeA } \\
\text { Scuola }\end{array}$ \\
\hline $\begin{array}{l}\text { PUCHTA, H.; STRANKS, J.; LEWIS } \\
\text { JONES, P. ; with KENNEDY, C.; } \\
\text { GREGSON, L. } \\
\text { BIANCO, C., GREGSON, L, with } \\
\text { LAMBRUSCHINI, M., DALPANE, C. } \\
\text { (TB) }\end{array}$ & $\begin{array}{l}\text { Get Thinking } \\
\text { (GT) }\end{array}$ & 2015 & $\begin{array}{l}\text { Cambridge } \\
\text { University Press }\end{array}$ \\
\hline
\end{tabular}

Recebido em: 08/08/2017 